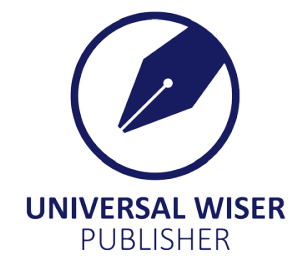

\title{
The Impact of Illicit Gold Mining on School Dropout: A Case of Senior High Schools in Asante Akim Municipality
}

\author{
Akosua Baah $^{1}$, Kwaku Owusu-Agyeman $^{2}$, Simon Boateng $^{1 *}$, Bosco Aboagye $^{1}$, Eric Twum Ampofo $^{3}$ \\ ${ }^{1}$ Social Sciences Department, Saint Monica's College of Education, P. O. Box MA250, Mampong-Ashanti, Ghana \\ ${ }^{2}$ Saint Monica's College of Education, P. O. Box MA250, Mampong-Ashanti, Ghana \\ ${ }^{3}$ Department of Educational Studies, University of Education, Winneba, Mampong Campus, Ghana \\ Email: boateng.simon@yahoo.com
}

Abstract: Studies indicate that there is a continuous relation between illicit mining and children's education. This study therefore, sought to examine the ramification of illicit mining on school dropout in the Asante Akim Central Municipality, Ghana. The purposive and simple random sampling techniques were used to select the respondents. A sample size of 360 was chosen for the study. Questionnaire and structured interview guide were used to collect the data. The correlational research design was used in the study. Linear regression, analysis of variance (ANOVA) and standard deviation were used to analyse the data. The study found the three leading factors that accounted for students to enter into illicit mining to be Poverty $(\mathrm{M}=3.9222, \mathrm{SD}=1.19169)$, perceived lack of employment opportunities after school $(\mathrm{M}=3.5972, \mathrm{SD}=1.42657)$ and disinterest towards schooling $(\mathrm{M}=3.5611, \mathrm{SD}=1.38501)$. The study further found a significant positive relationship between illicit mining and school dropout $(R=0.178, p<0.05)$, students' academic performance $(R=0.206, p<0.05$, $)$ and health risk and diseases $(\mathrm{R}=0.312, \mathrm{p}<0.05)$. Effective implementation of legal framework to prevent children of schoolgoing age from mining activities is imperative to ameliorate this educational menace. Again, vocational and technical education must be intensified to give such students employable skills in the shortest possible time.

Keywords: galamsey, school dropout, academic performance, social vices, mining policy

\section{Introduction}

Ghana and many other countries in the sub-Saharan Africa are blessed with an outstanding mineral endowment. Due to these large mineral deposits, mining in sub-Saharan Africa, particularly Ghana has become a major economic activity dating back to many years ${ }^{[1-4]}$. However, due to weak implementation of mining laws ${ }^{[5-7]}$, several natives and foreigners engage in illicit gold mining (galamsey) activities. Meanwhile, the impacts of galamsey on the environment, health and education are as many as the components that incite it ${ }^{[8-10]}$.

School children have been found to find solace in the illegal mining activity to the neglect of their education ${ }^{[5,11-14]}$. According to Thorsen ${ }^{[15]}$, one-third of all children in West Africa are estimated to work full or part-time, paid or unpaid. Many of these children are involved in hazardous and harmful activities in mines and the consequences on their education are immeasurable. Even if the work itself is not hazardous, many children do not have access to education due to the opportunity costs of school-going children keeping themselves at work ${ }^{[6,9,16-17]}$. However, some children combine work and school, and earning an income may enable them to continue their schooling. Nevertheless, the hard physical labour and long working hours in mining sites is one reason among many others why children may have difficulties in keeping up with school work ${ }^{[1-12,18]}$. In the long run, splendid and talented students who could have blossomed in education to assume the responsibility of the undertakings of the nation, wind up underground (pits) hunting for gold as destitute ${ }^{[13-14,19-20]}$.

It is imperative to note that several factors have been assigned to influence the practice of this illicit mining activity. For example, Ashigbey ${ }^{[9]}$ argues that illegal mining is a rational countervailing response to poverty. Hilson ${ }^{[21]}$ also reveals that Poverty is the main reason why most people engage in illegal mining. Dozome ${ }^{[22]}$ further ascribe factors such as poverty, broken homes and distance to school as causative agents to this galamsey (illicit mining) activity. While Osei$\operatorname{Tutu}^{[23]}$ and Silva ${ }^{[44]}$ found high unemployment rate to be the cause of illegal mining, Owusu ${ }^{[24]}$ asserts that students leave school to engage in galamsey because they perceive it to be a more lucrative venture. In spite of what the causes may be, poverty remains an outstanding causative factor.

Copyright (C2020 Simon Boateng, et al.

DOI: https://doi.org/10.37256/ser.122020553

This is an open-access article distributed under a CC BY license

(Creative Commons Attribution 4.0 International License)

https://creativecommons.org/licenses/by/4.0/ 
Repercussions of this illicit activity, particularly on school dropout cannot be overemphasised. Ankutse ${ }^{[18]}$ and Nozick $^{[45]}$ shows that many working children are denied access to education, or drop out of school due to the remoteness and time-consuming nature of their work. Others work to assume a very profound economic role in their families and many other children also work to earn income to buy necessities they need ${ }^{[7,25-26]}$. Whatever the push or pull factor may be, educational attainment and development of children regarding enrolment, performance and retention are always affected $^{[2,27-30]}$. Adjei ${ }^{[8]}$ and Parry ${ }^{[46]}$ also reveals that illegal mining activities have adverse effects on attendance in school. Addah $^{[1]}$ and Osei-Kuffuor ${ }^{[47]}$ posits that galamsey promotes child labour, inflation of prices, loss of farmlands, and depletion of the environment among other negative impact. Dozome ${ }^{[22]}$ and Quinlan ${ }^{[48]}$ puts it in a different perspective by stating that illegal mining activities hurt the child about the high rate of learners turnover and increment in adolescent pregnancy. Damien ${ }^{[25]}$ and Ghana News Agency ${ }^{[49]}$ further postulates that though illegal mining provides the households with lucrative incomes, there is little or no contribution of this income towards higher education. Worst of all the effects, Feigben ${ }^{[28]}$ and Gibbons ${ }^{[50]}$ gave a more elaborate perspective by showing a fierce competition which exists between child labour, school attendance and proficiency. Some of the young miners spend their money immediately and openly on sex and alcohol, which raises concerns for the moral environment children are living i in ${ }^{[31-36]}$. Children in mining have become a focus of attention as its links to many of the worst forms of child labour on the African continent which have become very obvious.

Galamsey among school going children and the youth, if left unchecked, will grow to destroy the moral fibre of our society since the youth constitute the soul and blood of the nation ${ }^{[51-53]}$. In the wake of finding solutions to ameliorate the effects of illicit mining, several studies have been conducted ${ }^{[15,24,26,37-38,]}$. That notwithstanding, all these considered the impact of illegal mining on the environment and livelihood neglecting the specific objective this study, thereby culminating into a research lacuna. Therefore, the thrust of this study is to explore the consequences of the illicit mining activity on school dropout in the Asante Akim Central Municipality.

\section{Materials and methods}

\subsection{Research design}

Correlational research design was applied in this study. Correlational research attempts to investigate possible relationships among variables without trying to influence those variables ${ }^{[39-40]}$. In the simplest form, correlational research is sometimes referred to as a form of descriptive analysis because it describes the relationship between variables. The correlational design was used because it helped the researchers to clarify their understanding of important phenomena through the quantification of relationships among variables.

\subsection{The study population}

The target population is the group of individuals that possess the information required by the researcher and about which inference is to be made ${ }^{[4]}$. The target population consisted mainly of all the Senior High School students in the Asante Akim Central Municipality. However, the accessible population were the two mixed public senior high schools (SHS) in the Asante-Akim Central Municipality, namely School A and B respectively for the sake of anonymity. At the time of the study, the SHS 1 students had not fully reported and that they were not included in the study. The population was 3365 as shown in Table 1.

Table 1. Students' population by class

\begin{tabular}{cccc}
\hline Variable & SHS 2 & SHS 3 & Total \\
\hline Senior High School A & 1058 & 936 & 1994 \\
Senior High School B & 571 & 600 & 1171 \\
Total & 1629 & 1536 & 3165 \\
\hline
\end{tabular}

\subsection{Sample size and sampling procedures}

The sample frame comprised all the Senior High School dropouts in the Asante Akim Central Municipality. For good quantitative analysis to be done, the research conveniently sampled 360 respondents who were Senior High School dropouts. Even though, the total number of dropouts was around six hundred (600) (refer from Table 6) in both schools over the last five year period at the time of data collection, the researcher deemed it fit to choose more than half (360) of the population. Since the research did not have the database on the identification of the respondents, Snow Sampling 
technique was appropriate for the selection of the respondents. Afterwards, purposive sampling technique was then used to select the two headmasters and four teachers from the two schools as key informants. According to Tongco ${ }^{[2]}$, purposive sampling technique is the deliberate choice of an informant due to the qualities the informant possesses. Finally, the snowball sampling technique was used to select the twenty (20) students who have stopped schooling and have gone into illicit mining.

\subsection{Sources of data and data collection instruments}

The researchers used both primary and secondary data. The main research instruments used were a questionnaire and structured interview guide. The two devices enabled the researchers to triangulate the findings to verify consistency from each of the tools utilised. Bekoe ${ }^{[16]}$ upheld this view when he expressed that triangulation in research is to test for consistency of findings obtained through different instruments. Primary data for the study was gathered through the administration of structured questionnaires to students and teachers of the two senior high schools. The interview was used to supplement the questionnaire. The researchers also reviewed existing secondary records on the enrolment data of the two senior high schools and the retention rate from the year 2010 to 2018 in the Municipal education office.

\subsection{Data analysis and presentation}

The quantitative data were analysed with the use of descriptive and inferential statistics. These data analysis tools included frequencies, simple percentages, standard deviation, Pearson Correlation Coefficient and Linear Regression. The Correlation Coefficient was used to determine the strength of relation that exists between illicit gold mining and school dropout. The findings were presented in tables and charts.

\section{Results and discussion}

Table 2 shows the demographic characteristics (Gender, Age, Schools, Religion) of respondents. The results show that $59 \%(n=211)$ were male while of $41 \%(n=149)$ were females. This may be as a result of the masculine nature of Ghanaian schools. Their age distribution shows that about $86 \%(\mathrm{n}=310)$ of the respondents were between $15-19$ years whilst $14 \%(n=50)$ were between $20-24$ years. The age distribution is not surprising as per Ghana's Educational structure and policy, many SHS students are mainly found within that age bracket. Again, 94.4\% $(n=340)$ of the respondents were Christians as against $6 \%(n=20)$ of the respondents being Muslims.

Table 2. Demographic characteristics of the respondents

\begin{tabular}{cccc}
\hline & Demographics & Frequency & Per cent \\
\hline \multirow{2}{*}{ Gender } & Male & 211 & 58.6 \\
& Female & 149 & 41.4 \\
\multirow{2}{*}{ Age } & $15-19$ & 310 & 86.0 \\
& $20-24$ & 50 & 14.0 \\
\multirow{2}{*}{ Religion } & Christianity & 340 & 94.4 \\
& Islam & 20 & 5.6 \\
\hline
\end{tabular}

Source: fieldwork Data, 2018.

\subsection{Factors that influence students into illicit gold mining}

Ten (10) factors were identified from the literature, and the respondents were asked to rate each element based on their level of agreement or disagreement with each factor. The results indicate that respondents agreed with each factor identified since the elements had an overall mean score of (3.857) and a standard deviation of (1.396). Each factor had a mean score which means that all the ten elements were indeed the factors that account for the illegal mining of students in school in the Asante Akim Central Municipality. The three leading factors that accounted for students to enter into illegal mining were Poverty, perceived lack of employment opportunity after school and poor academic performance with a high mean score of 3.9222, 3.5972 and 3.5611 with standard deviation of $1.19169,1.42657$ and 1.38501 respectively as shown in Table 3. 
Table 3. Factors accounted for students' engagement illegal gold mining

\begin{tabular}{ccccc}
\hline Variable & $\mathrm{N}$ & Mean & Std. D & Variance \\
\hline F1: poverty & 360 & 3.9222 & 1.19169 & 1.420 \\
F2: Lack of Employment Opportunity & 360 & 3.5972 & 1.42657 & 2.035 \\
F3: Inadequate Educational Facilities & 360 & 2.7000 & 1.40195 & 1.965 \\
F4: Desire to have Economic Freedom & 360 & 2.8639 & 1.47243 & 2.168 \\
F5: Poor Academic Performance & 360 & 3.5611 & 1.38501 & 1.918 \\
F6: Location of Students & 360 & 2.7889 & 1.38230 & 1.911 \\
F7: Lack of Parental Care & 360 & 2.8972 & 1.39557 & 1.948 \\
F8: Financial Problem & 360 & 3.3944 & 1.40035 & 1.961 \\
F9: High Educational Cost & 360 & 3.3028 & 1.40433 & 1.972 \\
F10: War & 360 & 2.6500 & 1.50199 & 2.256 \\
Overall & 360 & 3.16777 & 1.3962 & 1.9554 \\
\hline
\end{tabular}

Data Source: field work, October 2018.

\subsection{Effect of illicit gold mining on students}

In measuring the effect of illegal mining on students, four (4) effects were identified, and the participants were asked to show their level of agreement or disagreement with each outcome. The results suggest that respondents agreed with each effect identified. This was because the overall impact means score was (4.0253) and a standard deviation of (1.2189). The leading effects of illegal mining on students were school dropout, poor academic performance, diseases and health risk on the part of the students as shown in Table 4.

Table 4. Effect of illicit gold mining on students

\begin{tabular}{ccccc}
\hline Effect of Illegal Mining & N & Mean & Std.D & Variance \\
\hline School Dropout Rate & 360 & 4.1144 & 2.1169 & 1.322 \\
Academic Performance & 360 & 3.9394 & 1.2268 & 1.549 \\
Increases Social Vices & 360 & 3.7778 & 1.38256 & 1.911 \\
Diseases and Health Risk & 360 & 4.0407 & 1.2348 & 1.532 \\
Overall & & 4.02528 & 1.218928 & 1.5101 \\
\hline
\end{tabular}

Data Source: Field Work, 2018.

\subsection{Effects of illicit gold mining on school dropout}

Table 5 shows views of respondents on the effects of illicit mining on dropout in schools in the study area. Out of the 360 respondents, $309(85.8 \%)$ of the respondents said that dropout among school children had increased especially in Konongo where active mining activities are taking place. Besides, $41(11.4 \%)$ said that the dropout has decreased in the face of ongoing illicit mining activities due to the banning of galamsey by the government. Lastly, $10(2.8 \%)$ respondents said that illegal mining had no significant effect on drop out.

\subsection{Analysis of the secondary data}

A secondary data was obtained from the Municipal education office showing the enrolment and retention rate from 2010 to 2018. Trend analysis was done to find out some students who dropped out of school as results of illegal mining. 
Table 5. Trend analysis of students enrolled and the number of students who completed in a given period

\begin{tabular}{cccc}
\hline Academic Years & First Year & Second Year & Third Year \\
\hline $2010 / 2011$ to $2012 / 2013$ & 762 & 744 & 742 \\
$2011 / 2012$ to $2013 / 2014$ & 705 & 700 & 596 \\
$2012 / 2013$ to $2014 / 2015$ & 794 & 782 & 712 \\
$2014 / 2015$ to $2015 / 2016$ & 904 & 858 & 759 \\
$2015 / 2016$ to $2016 / 2017$ & 926 & 873 & 820 \\
$2016 / 2017$ to $2017 / 2018$ & 1018 & 962 & 936 \\
\hline
\end{tabular}

Source: Municipal Education Directorate, Asante Akim Central Municipality, 2018

The above table shows that as the enrolment keeps on increasing in every academic year, the retention rate keeps on decreasing as student move from the first year to the second year and finally the third year. This is due to illegal mining engaged in by students. While some students combine the mining work to that of the academic activities, others drop out of school and engage in it full time.

Table 6. The number of dropout students in schools

\begin{tabular}{cccc}
\hline Academic Years & No of stds admitted & Second Year & Third Year \\
\hline $2010 / 2011$ to $2012 / 2013$ & 762 & 50 & 20 \\
$2011 / 2012$ to $2013 / 2014$ & 705 & 15 & 17 \\
$2012 / 2013$ to $2014 / 2015$ & 794 & 36 & 70 \\
$2013 / 2014$ to $2015 / 2016$ & 904 & 46 & 106 \\
$2014 / 2015$ to $2016 / 2017$ & 926 & 53 & 106 \\
$2015 / 2016$ to $2017 / 2018$ & 1018 & 56 & 82 \\
\hline
\end{tabular}

Source: Municipal Education Directorate, Asante Akim Central Municipality, 2018

The Table 6 summarises the actual number of students who dropped out of school as a result of illicit mining engaged in by students in the senior high schools as students move from the first year to the second year and finally to the third year.

\subsection{Correlation analysis on the demographic characteristics of respondents}

The students identified the demographic factors that influence students to enter into illegal mining. The results show that there is no significant relationship between illicit mining and the following demographic characteristics; (Sex, Age and Religion) with correlation coefficients of $(\mathrm{R}=0.09,-0.08$ and 0.06$)$ respectively. There is a significant relationship between $(\mathrm{R}=0.129)$ illegal mining and schools (School A and School B). Thus, the rate of mining varies with the two schools under the study. The regression analysis shows that the demographic factors (sex, age, school and religion) of the students do not contribute significantly to illicit mining in the district, since p-values ( $\mathrm{Sig}=0.76, .110,0.60$ and $0.259>$ ) were all far greater than alpha level of 0.05 . The demographic factors (sex, age, school and religion) combined can only explained $2.2 \%\left(\mathrm{R}^{2}=0.022\right)$ of the total variability in illicit mining. This is illustrated in Table 7.

Table 7. Correlation analysis on the demographic characteristics of respondents

\begin{tabular}{ccc}
\hline Variable & Correlation & Illicit Mining \\
\hline \multirow{2}{*}{ Sex } & Pearson R & .094 \\
& Sig. (2-tailed) & .076 \\
\multirow{2}{*}{ Age } & Pearson R & -.084 \\
& Sig. & .110 \\
School & Pearson R & $-.129^{*}$ \\
& Sig. & .014 \\
Religion & Pearson R & .060 \\
& Sig. & .259 \\
Marital Status & Pearson R & .081 \\
& Sig. & .013 \\
\hline
\end{tabular}

Source: fieldwork data, 2018 


\subsection{The effect of illicit gold mining on students}

The impact of illegal mining was examined using regression and correlation analysis to quantify statistically, the effect of the illicit mining on the school dropout rate. The study found a significant positive relationship $(\mathrm{R}=0.178, \mathrm{p}<0.05)$ between school dropout and illegal mining as shown in Table 8 . There is no significant relationship between illegal mining and social vices on the part of the students who engage in illegal mining

Table 8. Correlation Analyses

\begin{tabular}{ccc}
\hline Pearson Correlation & Illicit mining & N \\
\hline Dropout School Rate & $.178^{*}$ & 360 \\
Academic & $.206^{*}$ & 360 \\
Disease And Health Risk & $.312^{* *}$ & 360 \\
Social Vices & 0.106 & 360 \\
\hline
\end{tabular}

*. Correlation is significant at the 0.05 level (2-tailed).

**. Correlation is significant at the 0.01 level (2-tailed)

\subsection{Regression analysis}

Following the significant relationship between the dependent variable; school dropout and illegal mining, regression analysis was used to estimate the contribution of the illicit mining on each of the dependent variable. The regression result was presented in Table 9 below and the results show that illegal mining contributes about $4.3 \%,\left(\mathrm{R}^{2}=0.043, \mathrm{P}<0.05\right)$ of the overall variation in the dependent variables. The regression model was significant, since the ANOVA $\mathrm{p}$-value $(\mathrm{Sig}=$ $0.044, \mathrm{p}<0.05$ ) was far less than 0.05 alpha level as shown in Table 9.

Table 9. ANOVA

\begin{tabular}{ccccccc}
\hline Dependent & Model & Sum of Squares & $\mathrm{df}$ & Mean Square & F & Sig. \\
\hline Dropout rate & Regression & 22.831 & 1 & 22.831 & 4.126 & $.044^{\mathrm{b}}$ \\
& Residual & 697.169 & 126 & 5.533 & & \\
& Total & 720.000 & 127 & & & \\
\hline
\end{tabular}

Note: Independent variable: Illegal Mining.

Source: Fieldwork data, 2018

\subsection{Discussion of results}

The study used the descriptive correlation to find the relationship between illicit mining and school dropout in the Asante Akim Municipality. The study found the three leading factors that influenced students into illicit mining to be poverty (parents' inability to provide for family needs), perceived lack of employment opportunity after school and disinterest towards schooling. This may be attributed to the "get-rich-quick' mentality of many youth in Ghana even though the issue of poverty may not be totally discounted. The mentality of many young people to live and present themselves in a luxurious lifestyle induces these students into this illicit activity (galamsey). This finding corroborates that of Ministry of Lands of Natural Resources ${ }^{[43]}$ and Human Right Watch Report ${ }^{[31]}$ that 'get-rich-quick' mentality lures many young people into illegal mining in Ghana.

The study further revealed that even though, Galamsey operation in actual fact impact people's lives positively in terms of income, its negative impact on school dropout was overwhelming. For instance, the study found a significant positive relationship between School Dropout Rate, Students' Academic performance, Disease and Health Risk and Illegal Mining. As the students develop the penchant for Galamsey activities, their attitudes towards school remain lackadaisical which affects their academic performance, thereby leading to school dropout. In furtherance, these students are exposed to myriad of environmental diseases because of massive pollution associated with the illicit mining activity. These findings are not different from that of $\mathrm{Addah}^{[1]}$ and Agbesi ${ }^{[5]}$ that illicit mining has not improved the wellbeing of the people in the communities where it is operated because they face several challenges and health risks as a result of the massive pollution.

\subsection{Conclusion and policy implication}

The impact of illicit mining on school dropout, health and other socio-economic such as poverty was shown in this study. The contemporary debates about illicit gold mining concerning its merits and demerits were repeated, but 
the negative sides dominated with respect to school dropout in accordance with the responses of the study participants. Therefore, it can be argued that illicit mining has not improved the wellbeing of the students in the study communities where it is operated because they face several challenges and health risks as a result of the massive pollution in the wake of the illicit mining. It can be concluded confidently that illicit mining worsens the plight of School going children because it lowers the academic performance.

The study concludes with some suggestions which are directed at helping to reduce illicit gold mining and its effects on school dropout. The researcher hopes that these recommendations if implemented, will contribute significantly to handling the menace created by illegal mining. Given the enormous control that chiefs continue to wield over lands, it is imperative that chiefs are brought on board as a major stakeholder in the fight against this illicit mining operation. Again, Students who cannot cope with the rigorous academic work in the senior high schools should as a matter urgency be referred to a professional or vocational institution or school. Skills acquired by students through technical and professional training would equip them to start their businesses after school or get employed after completing technical school or even the tertiary education. This would help students who are technically oriented or vocationally gifted not to drop out but be retained in school.

In addition, there should be effective implementation of legal framework to inhibit any child of school going age from engaging in this treacherous activity. If this strict policy is enforced, it will deter students of their involvement in illegal mining activities. This will reduce the high school dropout rate in senior high schools.

\section{Availability of data and material}

The datasets used and/or analysed during the current study are available from the corresponding author on reasonable request.

\section{Competing interests}

The authors declare that they have no competing interests.

\section{Funding}

This work was not supported by any organisation. Its contents are solely the responsibility of the authors.

\section{Author's contribution section}

We wish to state that all the authors have been personally and actively involved in substantive work leading to the research report. All the authors actively took part in the research design and data analysis of the manuscript preparation. We are therefore responsible for the content of this manuscript.

\section{References}

[1] Addah, Rita. Assessing the impact of galamsey operations on the socioeconomic Activities of Ghanaian rural mining communities: A Case Study of Ayamfuri. Ashesi Institutional Repository. 2014.

[2] UNICEF. Child Labour, Education and Policy Options. 2007. Available from: http://www.unicef.org.

[3] Verschuren PJM. Case study as a research strategy: Some ambiguities and Opportunities. International Journal of Social Research Methodology. 2003; 6(2): 121-139.

[4] Weston, BH. Child Labour and Human Rights: Making Children Matter. Boulder Colorado: Lynne, Rienner Publishing; 2005. Available from: http://www.h-net.org.

[5] Agbesi, KM. Galamsey menace causes, effects and solution. 2017. Available from: http://www.ghanaweb.com.

[6] Basu, K., Van, PH. The Economics of Child Labour. Oxford University Publishing; 2005.

[7] Eshun, AF. Business news (crude oil). 2017. Available from: http://www.ghanaweb.com.

[8] Adjei, A. The impact of illegal mining (galamsey) on cocoa production and livelihood: A Case Study of Amansie West District. Masters Thesis University of Education-Winneba Ghana. 2017.

[9] Ashigbey, I. The menace of illegal mining in Ghana. 2017. Available from: http://www.ghanaweb.com.

[10] Johnnie, D. Sampling Essentials: Practical guidelines for making Sampling Choices. California: Sage Publication Inc; 2012.

[11] Amanner. R. Children abandon school and go into illegal mining. Ghana News, Agency Report. 2009. Available 
from: http://www.asutifi.ghanadistricts.gov.gh.

[12] Anane, K. Effects of microfinance institution on Small and Medium Scale Enterprises In Rural Ghana: the case of the Jaman North District. Ghana: KNUST; 2012.

[13] Ayensu, SE. The African Legacy of the world's most precious metal. London: Marshall Edition Development Limited; 1997.

[14] R. Burke Johnson, Anthony J. Onwuegbuzie, Lisa A. Turner. Toward a Definition of Mixed Methods Research. Journal of Mixed Methods Research. 2014; 1(2): 112-133.

[15] Thorsen, D. Children in mines and quarries; Evidence from West and Central Africa. UNICEF Briefing paper. 2012. p.4. Available from: http://www.ilo.org/public/portugue.

[16] Bekoe, SOO. Assessment and curriculum goals and objectives: Evaluation of the systematic impact of the senior secondary school certificate examination (SSCE) on senior secondary school social studies curriculum in ghana. An unpublished doctoral dissertation. 2006.

[17] Cust, M., Cooper, W. Nozick's Lockean Provisos in his Initial Acquisition Theory. 2004. Available from: http://mises. org $/ \mathrm{pdf}$.

[18] Ankutse, B. Assessing the effects of mining on the educational life of children in Asutifi District of Ghana. KNUSTKumasi Ghana; 2016.

[19] Adarkwa, KK. Planning survey and research Methodology. 2014.

[20] Arah, IK. The impact of small-scale gold mining on mining communities in Ghana. African Studies Asociation of Australasia and the Pacific (AFSAAP) 37th, Annual Conference-Dunedin-New Zealand-25-26 November 2014 Conference Proceedings. 2015.

[21] Hilson, G. The Socio-Economic Impact of Artisanal and Small-Scale Mining in Developing Countries. Netherlands: sweets Publishing; 2003.

[22] Dozome, P. What is illegal mining and how significant is it? 2017. Available from: http://www.ghanaweb.com.

[23] Osei-Tutu, J. Learning and Earning in the Context of Small-Scale Gold Mining: Examining the Compatibility of Schooling and Work in the Lives of Working Young People in Ghana. Journal of Education and Social Research. 2017; 7: 3 .

[24] Owusu, EE. Land Use Disputes in Ghana's Mining Communities: Developing Sustainable Strategies. United Kingdom: BRASS Centre; 2013.

[25] Damien, M. Eliminating Child Labour through Education: The Potential for Replicating the work of the MV formation in India. Center for Development Studies, University College of Dublin; 2005.

[26] Liwanga, R. Why child mining in Africa Deserves American Attention. 2013. Available from: http://www.global Post. com.

[27] Essabra-Mensah, S. Sustainable small-scale gold mining in Ghana: setting and Strategies for sustainability, Geological Society. London: Special Publication; 2016.

[28] Feigben, J. Child Labour and Children's Education in the northern region of Ghana. Case Study of BunkpuruguYunyoo and East Mamprusi Districts. Ghana: Kwame Nkrumah University of Science and Technology; 2010.

[29] Gavin, WJ. Conceptual framework for Child Labour interventions in the Education Sector. ILO/IPEC Time-Bound Programme Manual for Action Planning Paper IV-2. Australia National University; 2003.

[30] Gyimah, AK. An introduction to research methods in education. The Institute for Educational Development and Extension. Winneba: University of Education; 2000.

[31] Human Right Watch Report. A poisonous Mix, Mercury and Artisanal Gold Mining in Mali. United States of America; 2011.

[32] International Labour Organisation. Ghana Child Labour Data: Country Brief. Geneva: ILO; 2008.

[33] International Labour Organisation. Every Child Counts: New Global Estimates on Child Labour. Geneva; 2002.

[34] International Labour Oganisation. The end of child labour: Within reach. 2002. Available from: http://www.ilo.org/ public/english/standard/relm/ilc95/pdf/rep-i-b.pdf.

[35] International Human Right Clinic. Digging in the Dirt. Child Miners in Sierra Leone Diamond Industries. Havard Law School; 2009. p.21-32. Available from: http://www.hrp.lawhavard.edu.

[36] International Institute for Environment and Development. IIED Shines a Light on Small-scale Mining. 2013. Available from: http://www.iied.org.

[37] Mahiyee, J. The status of education of mining Industry Professionals. England: IIED; 2013.

[38] Opoku-Antwi, G. L. Amofah, K., Nyamaah-Koffour, K. Comparative Study in the Bibiani, Bolgatanga, Dunkwa and Tarkwa Mining Districts of the Mineral Commission of Ghana. Journal of International Energy Policy. 2012; 1(1):1920.

[39] Miller, R. L., Brewer, J. D. A-Z of Social Research. London: SAGE Publication Limited; 2003.

[40] Yin, RK. Case Study Research, 3rd edu. London, England: Sage Publications; 2003. 
[41] Creswell, JW, Plano CV L. Designing and conducting mixed method research. Thousand Oaks, CA: Sage; 2011.

[42] Tongco, DW. Qualitative Interview Design: A Practical Guide for Novice Investigators. The Qualitative Report. 2007.

[43] Ministry of Lands and Natural Resources. Project Appraisal \& Implementation Document for the Multilateral Integrated Project. Accra: JMK Consulting, LLc; 2017.

[44] Silva, O. School retention and child labour prevention programme: Ministry of Labour, Human Services in Social Security. 2013. Available from: http://www.chldlabourdialogues.org.

[45] Nozick, FK. Influence of land tenure practices on artisanal mining activity in Ghana. Resource Policy. 2010; 35(1): 47-53.

[46] Parry, N. M. Factors inhibiting illegal miners in the Upper Denkyira East District in Central Region from registering with the minerals commission of Ghana. Legon: University of Ghana; 2014.

[47] Osei-Kuffour, G. The Impact of Illegal Mining on the Ghanaian Youth: Evidence From Kwaebibirem District in Ghana. Research on Humanities and Social Sciences. 2013: 2(6).

[48] Quinlan, A. Technical Report on the Kibi Goldfields Mine Kwabeng Gold Project Ghana. West Africa; 2011. Available from: http://chevyrockengineering.com.

[49] Ghana News Agency. Galamsey menace causes, effects and solution. 2017. Available from: http://www.ghanaweb. com/news.

[50] Gibbons, ED, Huebler, F., Loaiza, E. Child labour, Education and the principle of non-discrimination. UNICEF New York; 2005.

[51] Ghana News Agency. Seventeen galamsey operators crush to death at Kyekyewere. 2013. Available from: http://www. modernghana.com/news.

[52] Ghana News Agency. Final year SHS student swallowed by the galamsey pit. 2018. Available from: http://www. ghanaweb.com/news.

[53] Ghana News Agency. The history of oil discovery in Ghana. 2018. Available from: http://www.ghanaweb.com/news. 